\title{
Determination of Volatile Constituents of the Essential Oil and Absolute of Nyctanthes arbortristis L. Flowers Grown in the Wet Zone of Sri Lanka
}

\author{
V.S. Siriwardena* and L.S.R. Arambewela \\ College of Chemical Sciences, Institute of Chemistry, Rajagiriya, Sri Lanka
}

Date Received: 17-01-2014 Date Accepted: 01-08-2014

\begin{abstract}
The volatile constituents of the essential oil and absolute of Nyctanthes arbortristis L. flowers grown in the wet zone of Sri Lanka were investigated in this study. Hydro-distillation and solvent extraction methods were used to obtain the essential oil and the absolute respectively. The volatile samples were analysed by GC-MS techniques. This study led to the identification of 48 chemical constituents of the essential oil and 4 in the absolute. The essential oil composition was dominated by phytol (32.2\%) and methyl palmitate (14.7\%). Other well-known volatile constituents such as linalool $(0.8 \%)$, eucarvone $(0.9 \%)$, phytone $(1.4 \%)$, nonadecane $(2.3 \%)$, methyl myristate $(1.1 \%)$, cis-9tricosene $(3.6 \%)$, n-pentacosane $(1.6 \%)$ and geranylgeraniol $(2.7 \%)$ were also identified in the essential oil. The absolute was dominated by butyl acetate $(80.8 \%)$ followed by phenethyl acetate $(1.7 \%)$, linalool oxide (1.4\%) and 2-butoxyethyl acetate (1.4\%).
\end{abstract}

Keywords: Nyctanthes arbortristis, essential oil composition, methyl palmitate, phytol; absolute

\section{Introduction}

Nyctanthes arbortristis L. is a large shrub with fragrant flowers that open at dusk and finish at dawn, and belongs to the family Oleaceae, to which Jasminum species also belongs. The plant is also known as Coral Jasmine or Sepalika in Sinhala (Moldenke and Moldenke, 1983). Its flowers are perceived to have fragrance "similar to jasmine" (The Wealth of India, 1997) and could be described on simple terms so as to possess saffron spicy, honey suckle, sweet floral hints of jasmine (http://www.evanhealy.com/home/article/35). Nyctanthes arbortristis is grown in Asian countries like Sri Lanka, India, Thailand, Indonesia, etc. (Moldenke and Moldenke, 1983). Its flowers usually bloom from July to October and constitute of white petals fixed to a bright orange tubular stalk (Sandhar et al., 2011). Folk people of Tripura of India predict the weather and rainfall variation based on the analysis of total number of flowers and this was scientifically validated by (Acharya, 2011).

Nyctanthes arbortristis flowers are bitter, astringent, carminative, stomachic and used in ophthalmic purposes. They are also used as a tonic to the hair in preventing graying of hair and baldness (Sasmal et al., 2007). Flowers are also used traditionally to provoke menstruation (Champa et al., 2012).

\footnotetext{
*Correspondence: viransanjaya@yahoo.com

Tel: +61423250689

ISSN 2235-9370 Print/ISSN 2235-9362 Online (C) University of Sri Jayewardenepura
} 
In vitro antiplasmodial activity (Champa et al., 2012) and antifilarial activity (Sandhar et al., 2011) were shown by ethanolic and chloroform extracts of the flowers respectively. Both these activities could be attributed to the occurrence of Rengyolone which is a non-cytotoxic compound (Sasmal et al., 2007). The hot flower infusion of $N$. arbortristis was reported to have sedative and diuretic effects on rats (Ratnasooriya and Jayakody, 2004; Sasmal et al., 2007). The isolated carotenoid aglycone Ag-NY1 from the orange colored tubular calyx of flowers, exhibited good membrane stabilising activity as described (Sandhar et al., 2011). Three other carotenoid glycosides were also isolated from the corolla tubes of the plant (Vankar, 2008). The ethanolic extract of the orange tubular calyx of $N$. arbortristis and the isolated carotenoid showed significant inhibition of rat paw edema (Champa et al., 2012). It was demonstrated that $N$. arbortristis flowers exhibit various beneficial bioactivities, including antispasmodic, antidiabetic, antihelmintic and immunostimulant, antiinflammatory and hepatoprotective activities (Sandhar et al., 2011).

Studies suggest that flowers have somewhat less antioxidant capacity than the leaves. It has been proven that the water extract of flowers has radical scavenging activity with their calyx having the most (Vankar, 2008). Both enzymatic and non-enzymatic antioxidants in the flowers have been investigated by (Ramapriya and Usha, 2010). They have found that there is significant difference in the two levels of antioxidant assays. Work carried out by (Nagavani et al., 2010) also supports the above conclusion.

The flowers were reported to contain coloring matter Nyctanthin (identical with $\alpha$-crocetin from saffron) as well as D-mannitol, tannin, iridoid glycosides (Sandhar et al., 2011). The oil obtained by the water distillation method (yield, $0.0045 \%$ ) was soluble in absolute alcohol with slight turbidity as described (The Wealth of India, 1997). The concrete was obtained by extraction with benzene and a $0.058 \%$ yield (The Wealth of India, 1997). The essential oil contains $\alpha$-pinene, p-cymene, 1-hexanol, methylheptanone, phenylacetaldehyde, 1-decanol and anisaldehyde as described (Champa et al., 2012). Another study carried out on flowers of Bangladesh (Rahman et al., 2011) reported phytol and 2methyloctadecane as major constituents from the essential oil of petal and corolla tube, respectively.

Although Sri Lankan Ayurveda system uses the plant for its medicinal applications, the Sepalika plants grown in Sri Lanka were less studied, except for a few work cited in literature (Ratnasooriya and Jayakody, 2004; Ratnasooriya et al., 2005). As the volatile constituents of $N$. arbortristis flowers grown in Sri Lanka have not been studied the aim of present study is to characterize the volatile constituents of the essential oil and absolute of local $N$. arbortristis flowers.

\section{Methodology}

\subsection{Plant material}

Nyctanthes arbortristis flowers were picked from the ground early morning before sunrise from Pannipitiya in Sri Lanka, and taken to the laboratory for distillation and extraction. The plant was identified at the Herbarium of Royal Botanical Gardens, Peradeniya, Sri Lanka.

\subsection{Hydro-distillation of flowers}

Fresh flowers were hydro-distilled for five hours using a Clevenger type apparatus. A mixture of 1:1 hexane and pentane was used to trap the essential oil. After distillation, the trapped essential oil was dried using anhydrous $\mathrm{Na}_{2} \mathrm{SO}_{4}$ and the essential oil was recovered. 


\subsection{Preparation of the absolute}

Fresh flowers were cut into small pieces and soaked overnight in hexane. The hexane layer was collected and evaporated under reduced pressure. This afforded a semi-solid, dark orange concrete of $N$. arbortristis flowers. Next the concrete was extracted with ethanol. The waxes were filtered off and the ethanol extract was concentrated.

\subsection{Analysis of the essential oil using Gas Chromatography-Mass Spectrometry (GC-MS)}

GC-MS analysis was performed on Agilent 5973 instrument using Restek carbowax column $(30 \mathrm{~m} \times 0.25 \mathrm{~mm}$ i.d., $0.25 \mu \mathrm{m}$ film thickness) coated with polyethyleneglycol and coupled with a 5973 Network Mass Selective detector (Agilent). Chromatographic conditions: helium was used as carrier gas at $1.0 \mathrm{~mL} / \mathrm{min}$. Splitless injection of $1.0 \mu \mathrm{L}$ of oil. Injector temperature was $230^{\circ} \mathrm{C}$; oven temperature program: initial temperature $40^{\circ} \mathrm{C}$ (held for 5 minutes), raised to $220^{\circ} \mathrm{C}$ at $6^{0} \mathrm{C} / \mathrm{min}$ and held for 17 minutes. MS interface temperature: $230^{\circ} \mathrm{C}$, MS mode: EI, ionization voltage: $70.1 \mathrm{eV}$. Compounds were identified using Wiley+Nist database library. The percentages of constituents were calculated leaving out the solvent peak as well as background peaks.

\subsection{Analysis of the absolute using Gas Chromatography-Mass Spectrometry (GC-MS)}

GC-MS analysis was performed on Agilent 5973 instrument using a column $(30 \mathrm{~m} \times 0.25 \mathrm{~mm}$ i.d., $0.25 \mu \mathrm{m}$ film thickness) coated with (5\%-Phenyl)-methylpolysiloxane and coupled with a 5973 Network Mass Selective detector (Agilent). Same chromatographic conditions as above were used except that the injection was in split mode (1:100). Oven temperature program: initial temperature $50^{\circ} \mathrm{C}$ (held for 1 minute), raised to $244^{\circ} \mathrm{C}$ (held for 1 minute), final temperature $300^{\circ} \mathrm{C}$ (held for 5 minutes). MS parameters were the same as above. The identification and calculation of composition was carried out as above.

\section{Results and Discussion}

The hydro-distillation of the flowers of $N$. arbortrisitis yielded $0.06 \%$ (w/w, wet basis) or 0.76 $\%$ (w/w, dry basis) of fragrant essential oil. The essential oil obtained had a light yellow color with a strong floral odor. It congealed at temperatures around $25^{\circ} \mathrm{C}$.

The maceration of flowers in hexane yielded $0.06 \%$, concrete (w/w, based on fresh plant material). The yield is quite similar to the earlier reported value of $0.058 \%$ by Gupta et al. in 1954 (The Wealth of India, 1997).

The chromatograms of the essential oil and the absolute obtained in the GC-MS analysis are presented in Figure 1 and Figure 2. The results of GC-MS analysis are summarized in Table 1 and Table 2. Around forty eight compounds were identified in the essential oil and four in the absolute. 


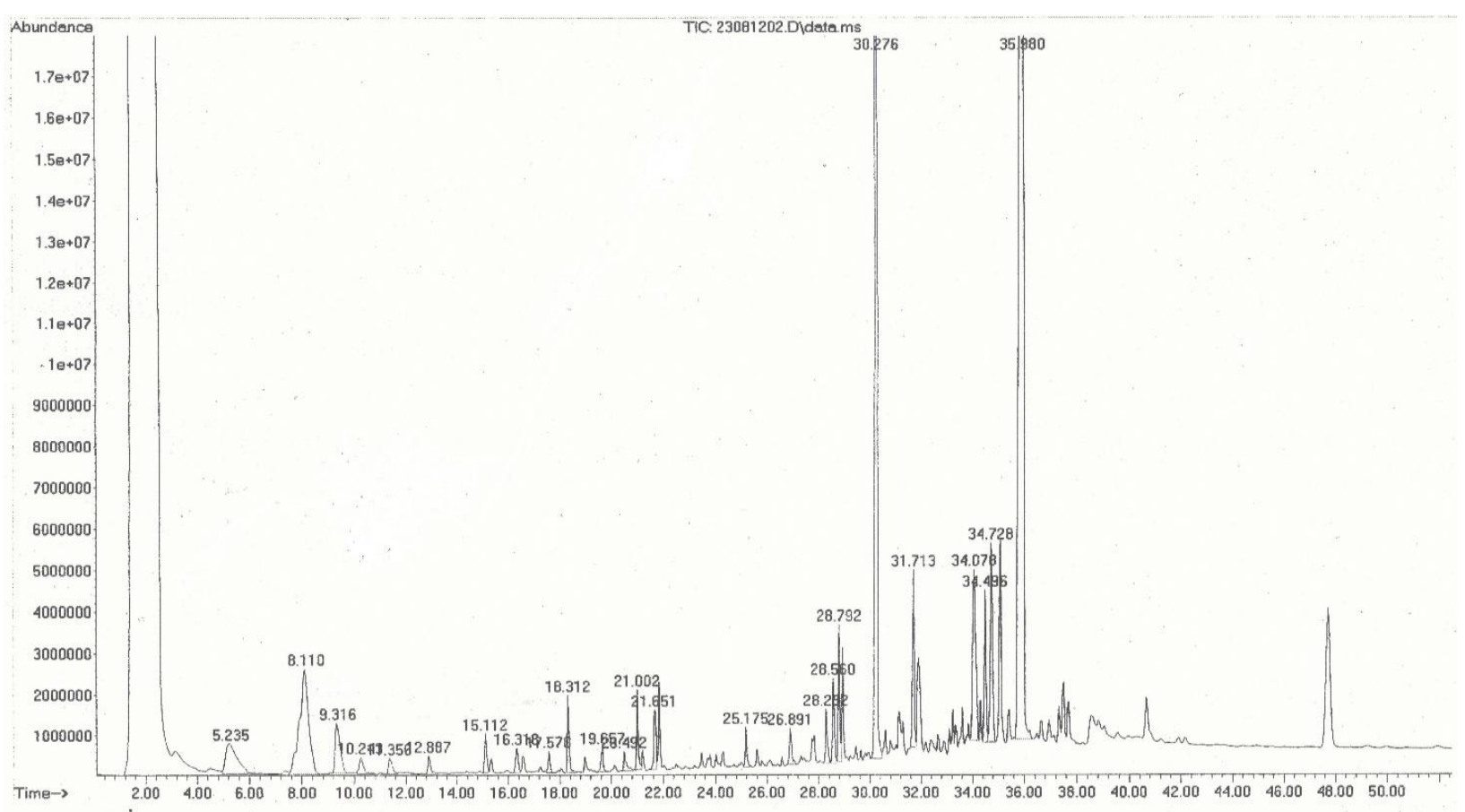

Figure 1: GC/MS chromatogram of the essential oil of $N$. arbortristis flowers from Sri Lanka.

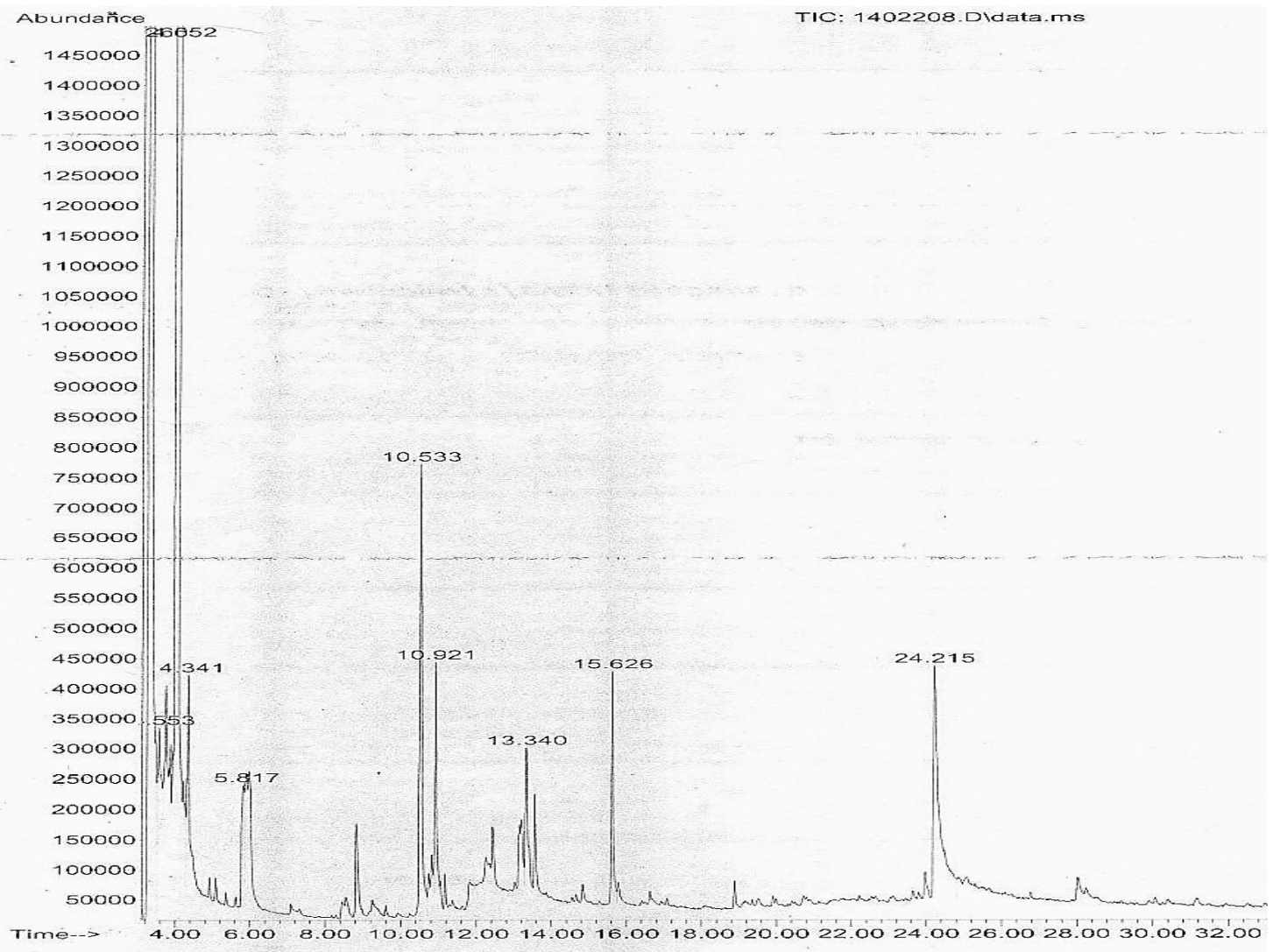

Figure 2: GC/MS chromatogram of the absolute of N. arbortristis flowers from Sri Lanka. 
Table 1: Chemical constituents of the essential oil of N. arbortristis flowers grown in Sri Lanka.

\begin{tabular}{|c|c|c|}
\hline $\begin{array}{l}\text { Retention } \\
\text { time }\end{array}$ & $\begin{array}{l}\text { Compounds } \\
\text { identified }\end{array}$ & $\begin{array}{l}\text { \% Composition } \\
\text { in essential oil }\end{array}$ \\
\hline 4.49 & n-Decane & 0.1 \\
\hline 7.36 & n-Undecane & 0.1 \\
\hline 10.24 & n-Dodecane & 0.4 \\
\hline 11.35 & Styrene & 0.3 \\
\hline 12.88 & n-Tridecane & 0.3 \\
\hline 15.11 & $\beta$-Isophorone & 0.5 \\
\hline 15.33 & n-Tetradecane & 0.2 \\
\hline 15.99 & Linalool Oxide & 0.1 \\
\hline 16.32 & n-Hexadecane & 0.4 \\
\hline 16.55 & $\alpha$-Ionone & 0.2 \\
\hline 17.57 & Benzaldehyde & 0.3 \\
\hline 18.31 & Linalool & 0.8 \\
\hline 18.96 & $\alpha$-Isophorone & 0.2 \\
\hline 19.65 & Methyl benzoate & 0.4 \\
\hline 20.12 & Safranal & 0.1 \\
\hline 20.49 & 1-Hexadecene & 0.3 \\
\hline 21.00 & 4-Oxoisophorone & 0.8 \\
\hline 21.18 & Terpineol & 0.2 \\
\hline 21.65 & Eucarvone & 0.9 \\
\hline 21.84 & Azulene & 0.9 \\
\hline 22.48 & Epoxylinalol & 0.1 \\
\hline 22.85 & Methyl salicylate & 0.1 \\
\hline 23.18 & cis-Geraniol & 0.1 \\
\hline 23.46 & n-Octadecane & 0.2 \\
\hline 24.01 & trans-Geraniol & 0.1 \\
\hline 24.29 & 1-Octadecene & 0.2 \\
\hline 25.59 & Neophytadiene & 0.2 \\
\hline 26.89 & Methyl myristate & 0.5 \\
\hline 27.81 & Hexyl benzoate & 0.5 \\
\hline 28.56 & n-Heneicosane & 0.9 \\
\hline 28.79 & Phytone & 1.4 \\
\hline 29.44 & Methyl iso-palmitate & 0.1 \\
\hline 29.63 & n-Eicosane & 0.1 \\
\hline 30.27 & Methyl palmitate & 14.7 \\
\hline 30.60 & Methyl palmitoleate & 0.2 \\
\hline 30.79 & Ethyl palmitate & 0.2 \\
\hline 31.71 & n-Nonadecane & 2.2 \\
\hline 33.24 & Methyl stearate & 1.1 \\
\hline 33.62 & Methyl 11-octadecenoate & 0.4 \\
\hline 33.85 & n-Docosane & 0.3 \\
\hline 34.08 & cis-9-Tricosene & 3.6 \\
\hline 34.49 & n-Pentacosane & 1.6 \\
\hline 34.72 & Geranylgeraniol & 2.7 \\
\hline 35.98 & Phytol & 32.2 \\
\hline 36.67 & n-Tricosane & 0.3 \\
\hline 37.51 & n-Heptacosane & 0.8 \\
\hline 38.53 & Benzyl salicylate & 1.1 \\
\hline 40.66 & Geranyl linalool isomer & 0.9 \\
\hline
\end{tabular}


Table 2: Chemical constituents of the absolute of N. arbortristis flowers grown in Sri Lanka.

\begin{tabular}{rlc}
\hline $\begin{array}{l}\text { Retention } \\
\text { Time }\end{array}$ & Compounds Identified & $\begin{array}{c}\text { \% Composition in } \\
\text { the Absolute }\end{array}$ \\
\hline 4.05 & Butyl acetate & 80.8 \\
10.92 & 2-Butoxyethyl acetate & 1.4 \\
13.34 & Linalool oxide & 1.4 \\
15.62 & Phenethyl acetate & 1.7 \\
\hline
\end{tabular}

The major volatile constituents in the essential oil were phytol (3,7,11,15-tetramethyl-2-hexadecene-1ol) and methyl palmitate. Phytone, nonadecane, methyl stearate, cis-9-tricosene, n-pentacosane, geranylgeraniol and benzyl salicylate were also present in the essential oil. Among the minor constituents, well-known fragrant compounds like linalool oxide, terpineol, eucarvone, geraniol, etc. were present. A range of alkanes starting from n-decane to n-heptacosane were also present in the essential oil. Fatty acid esters such as palmitates, methyl myristate and stearate were characterized from the essential oil. Two salicylates (methyl and benzyl) and two benzoates (methyl and hexyl) were also present in the flower oil. Compounds like isophorones, ionones and safranal could be formed by thermal degradation of carotenoids present in N. arbortristis flowers due to heat applied during hydrodistillation. Butyl acetate was the major compound in the absolute. Also it is noteworthy that out of four compounds identified in the absolute three were acetates.

The study carried out on flowers of Bangladesh reported phytol and 2-methyloctadecane as major constituents from the essential oil of petal and corolla tube, respectively (Rahman et al., 2011). Therefore there are some similarities between the essential oils of flowers of the two countries.

Nyctanthes arbortristis floral fragrance could be perceived "similar to jasmine" (The Wealth of India, 1997) due to the presence of following volatile constituents in both Jasminum species and $N$. arbortristis flowers: linalool, methyl palmitate, phytol, benzaldehyde, methyl salicylate, methyl benzoate, linalool oxide, terpineol, geraniol, geranyl linalool, methyl octadecanoate (http://www.pherobase.com). Thus, $N$. arbortristis could be used instead of jasmine for fragrant purposes. Therefore, it could be concluded that $N$. arbortristis flowers of Sri Lanka are a good source of fragrance for cosmetic industry.

\section{Acknowledgements}

The authors gratefully acknowledge the facilities and financial assistance provided by the College of Chemical Sciences to carry out this work.

\section{References}

Acharya, S. 2011. Prediction of rainfall variation through flowering phenology of night-jasmine in Tripura. Indian Journal of Traditional Knowledge, 10: 96-101.

Champa, R., Chawla, S., Mangal, M., Mangal, A.K., Kajla, S. and Dhawan, A.K. 2012. Nyctanthes arbortristis Linn. (Night jasmine): A sacred ornamental plant with immense medicinal potentials. Indian Journal of Traditional Knowledge, 11:427-435.

El-Sayed, A.M. 2014. The pherobase: Database of pheromones and semiochemicals. http://www.pherobase.com. Accessed 01 February 2014.

Healy, E. 2014. Parijata blossom attar. Evanhealy the skin breathes. http://www.evanhealy.com/ home/article/35. Accessed 01 February 2014. 
Moldenke, H.N. and Moldenke, A.L. 1983. Nyctanthaceae, In: Moldenke, H. N., Moldenke, A.L., Dassanayake, M.D., Fosberg, F.R. (Eds.), A Revised Handbook to the Flora of Ceylon. Amerind Publishing Co. Pvt. Ltd., New Delhi, 4, pp.178-181.

Nagavani, V., Raghava, R.K.V., Ravi, K.C. and Raghava, R.T. 2010. In vitro screening of Nyctanthes arbortristis flowers for antioxidant activity and identification of polyphenols by RP-HPLC. Pharmacologyonline, 2: 57-78.

Rahman, M.M., Roy, S.K., Hussain, M. and Shahjahan, M. 2011. Chemical constituents of essential oil of petals and corolla tubes of Nyctanthes arbortristis Linn. flower. Journal of Essential Oil Bearing Plants, 14(6): 717-721.

Ramapriya, R. and Usha, K. 2010. Antioxidant potential of the leaves and flowers of Nyctanthes arbortristis Linn. Advanced BioTech, 9(7): 40-42.

Ratnasooriya, W.D. and Jayakody, J.R.A.C. 2004. Diuretic activity of hot flower infusion of Nyctanthes arbortristis in rats. Boletin Latinoamericano y del Caribe de Plantas Medicinales $y$ Aromaticas, 3(5): 84-87.

Ratnasooriya, W.D., Jayakody, W.D., Hettiarachchi, A. D. I. and Dharmasiri, M.G. 2005. Sedative effects of hot flower infusions of Nyctanthes arbortristis on rats. Pharma. Biol., 43(2): 140-146.

Sandhar, H.K., Kaur, M., Kumar, B. and Prasher, S. 2011. An update on Nyctanthes arbortristis Linn. Internationale Pharmaceutica Sciencia, 1(1): 77-86.

Sasmal, D., Das, S. and Basu, S.P. 2007. Phytoconstituents and therapeutic potential of Nyctanthes arbortristis Linn. Pharmacognosy Reviews, 1(2): 344-349.

The wealth of India: A dictionary of Indian raw materials and industrial products, 1997. National Institute of Science Communication, CSIR, New Delhi, pp. 69-70.

Vankar, V.S. 2008. Antioxidant activity of the flower of Nyctanthes arbortristis L. International Journal of Food Engineering, 4(8): 11. 